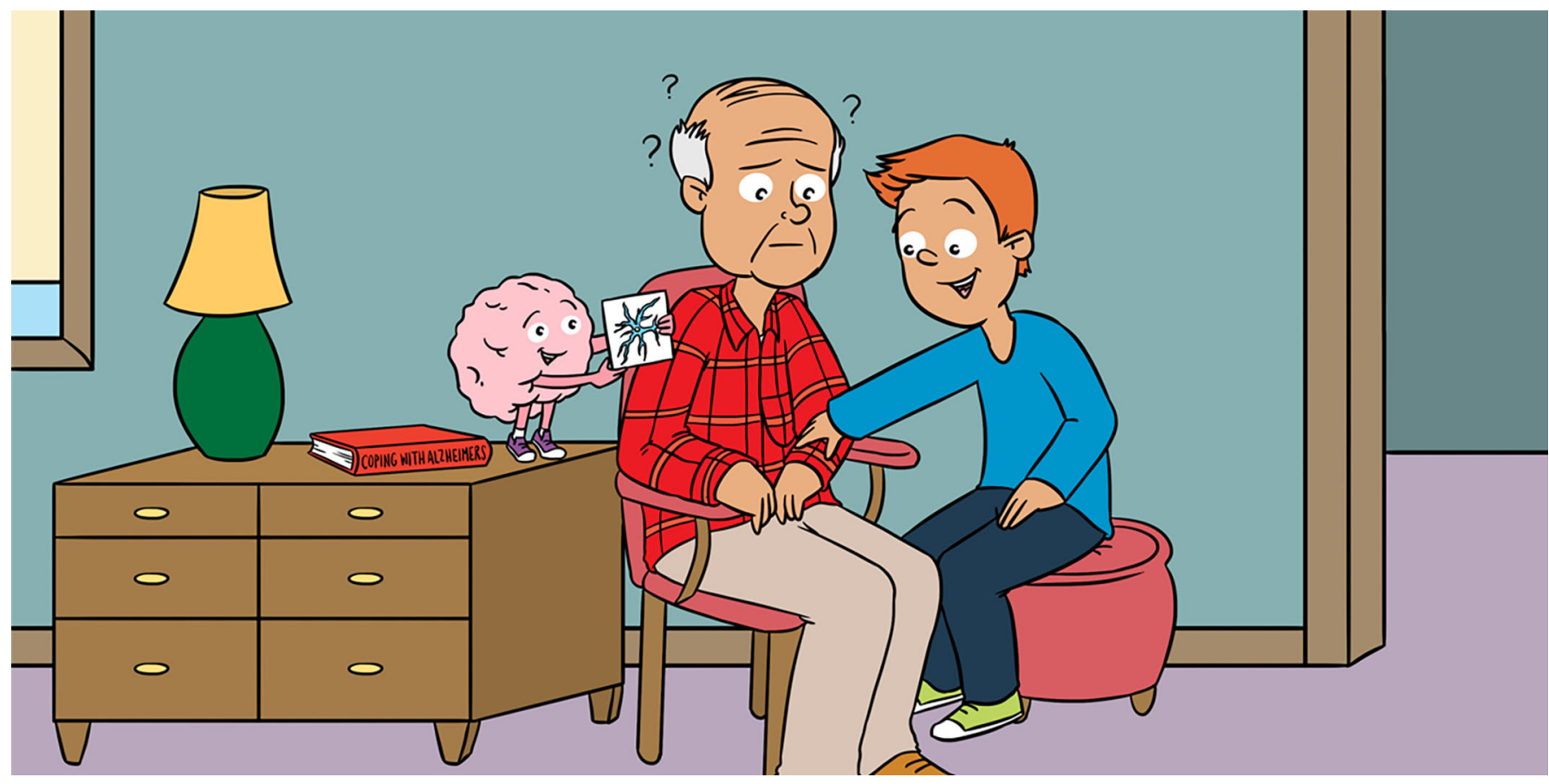

\title{
UNDERSTANDING HUMAN ASTROCYTES: THE NEGLECTED STARS OF THE BRAIN
}

\section{Benjamin Clarke ${ }^{1,2^{*}}$, Helen Devine ${ }^{1,2}$, Jacob Neeves ${ }^{1,2}$ and Rickie Patani ${ }^{1,2}$}

${ }^{1}$ Human Stem Cells and Neurodegeneration Laboratory, The Francis Crick Institute, London, United Kingdom

${ }^{2}$ Department of Neuromuscular Disease, University College London Queen Square Institute of Neurology, London, United Kingdom

\section{YOUNG REVIEWERS:}

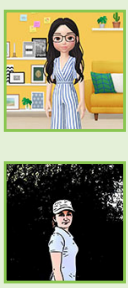

LIJIA

AGE: 13

MARILIA

AGE: 13

The majority of neuroscience research has focused on nerve cells called neurons. But there are just as many star-shaped cells called astrocytes in the brain. In this article, we discuss how astrocytes have many really important roles for keeping neurons healthy. We also describe how scientists are using stem cell technology to study human astrocytes and how astrocytes go wrong in neurodegenerative diseases like Alzheimer's disease, Parkinson's disease, and motor neuron disease.

\section{WHAT ARE ASTROCYTES?}

\section{ASTROCYTE}

(a-strow-site): A star-shaped cell that keeps neurons healthy in the brain.

You might know that the brain contains a huge number of nerve cells (also called neurons), but have you heard of another type of brain cell that is just as common-astrocytes? 
Figure 1

Astrocytes support neurons in several different ways. They make sure neurons are well fed by giving them nutrients and controlling blood flow, they clean up after neurons by recycling neurotransmitters, and they protect neurons from harm by releasing certain cytokines to activate an immune response, destroying infection or guarding the neurons from injury.

\section{NEURODEGENERATIVE} DISEASES

A group of illnesses where neurons deteriorate and die, affecting brain function.

\section{SYNAPSE}

(si-naps): The junction where neurons communicate with one another.

\section{NEUROTRANSMITTER}

(nyu-row-tranz-mi-tuh): A chemical signal that transmits messages between neurons.

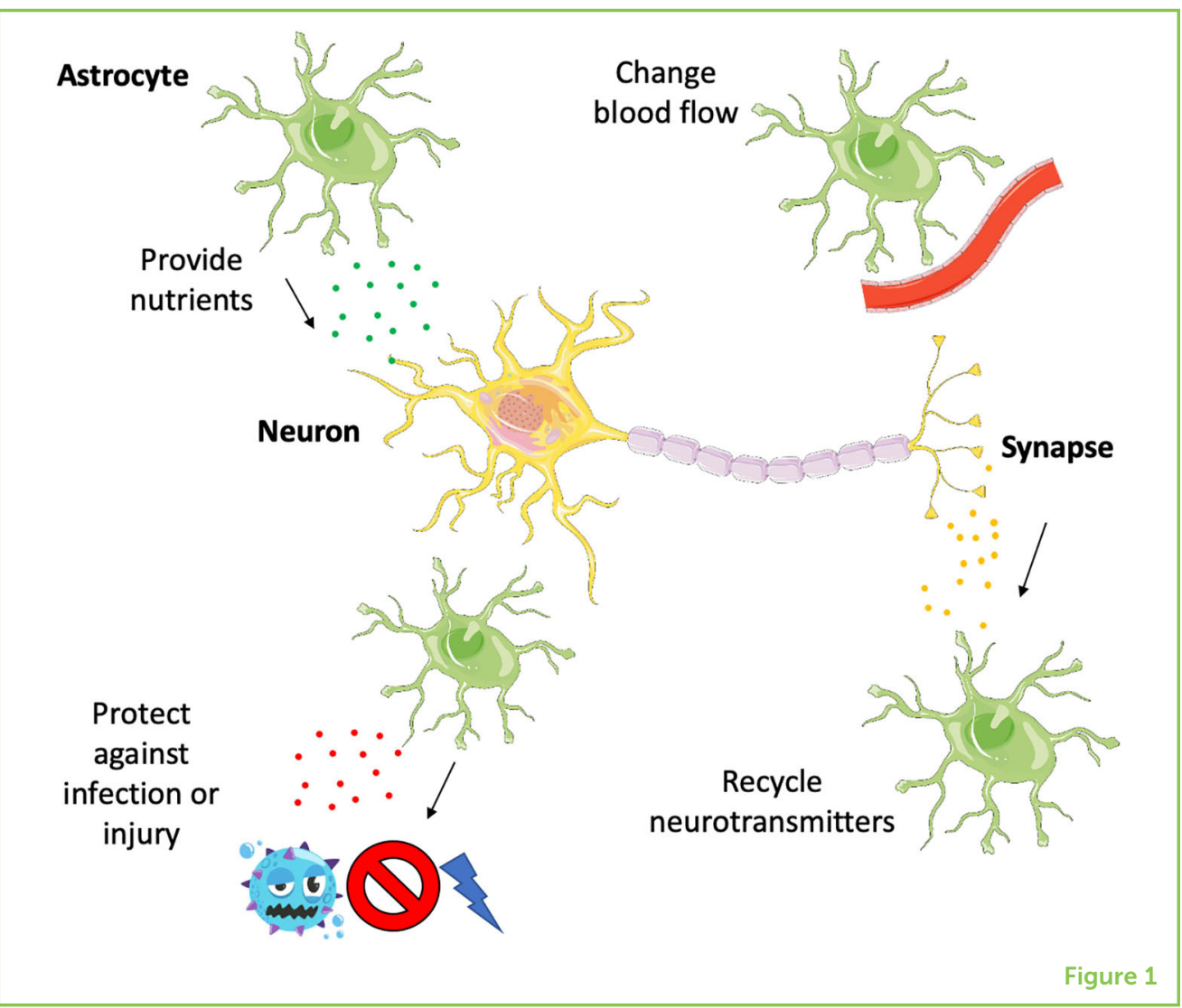

Named because they look a bit like stars, astrocytes are very important for normal brain function. When astrocytes do not work properly, they can also play a big role in what goes wrong in diseases of the brain, called neurodegenerative diseases, like Alzheimer's disease, Parkinson's disease, and motor neuron disease [1]. Finding out how astrocytes work and what happens when they go wrong in disease is really important for discovering new therapies to treat neurodegenerative diseases.

\section{WHAT DO ASTROCYTES DO?}

Astrocytes have several really important roles in the brain, helping to make sure that neurons stay alive and communicate with each other in the correct way (Figure 1). Astrocytes act as a sort of vending machine for neurons - they release molecules that neurons use to make energy so that they can keep working properly. In addition, astrocytes regulate the way neurons get their nutrients by interacting with blood vessels to control blood flow to certain areas of the brain.

Astrocytes also play an important role at the junctions between neurons that the neurons use to communicate with each other, called the synapse. A neuron on one side of the synapse will send a message across the synapse to another neuron, in the form of a chemical signal called a neurotransmitter. After the neurotransmitter is released 


\section{CYTOKINE}

(sai-toe-kyn): A type of immune molecule that can be released by astrocytes in response to infection or injury.

\section{STEM CELL}

A cell that has the ability to make more of itself and specialize into a different type of cell.

\section{Figure 2}

Shinya Yamanaka won the Nobel Prize in 2012 for his work on iPSCs. He found a way to turn specialized cells back into stem cells so that they can then be turned into any type of cell. This made it a lot easier to study human neurons and astrocytes, because these cells could be grown from iPSCs.

at the synapse and the message is received by the other neuron, astrocytes remove the neurotransmitter and recycle it so that it can be used again.

When infection or injury occurs in the brain, astrocytes respond by releasing a special set of chemicals called cytokines. By doing this, astrocytes direct the immune response to the damaged part of the brain, limiting the extent of the damage and protecting neurons by releasing other molecules that help them survive.

Many of the roles that astrocytes play to keep neurons healthy are now known to go wrong in neurodegenerative diseases. Scientists have found that, in some diseases, astrocytes do not provide nutritional support as well as they do in non-diseased brains. Diseased astrocytes also do not recycle neurotransmitters as well, and they may release certain cytokines that are actually harmful to neurons, rather than protective.

Because astrocytes are located in the brain, it is very difficult to study them. We cannot just take a piece of brain from a person, because that would cause the person permanent damage. In the past, scientists have studied astrocytes by taking them from animals like worms, fish, or mice. However, human astrocytes are thought to be much more complex than astrocytes from animals. Therefore, we know that studying human astrocytes is important, but how might this be possible?

\section{USING STEM CELLS TO MAKE ASTROCYTES}

Recently, advances in stem cell technology have made it possible to make human astrocytes in a laboratory dish, so that we can easily study them. But what are stem cells?

Every person begins life as just one cell, containing material from both parents. That one cell grows and then splits in half to make two cells, those two cells grow and then split in half to become four cells. This process keeps going and going, to eventually make a person made

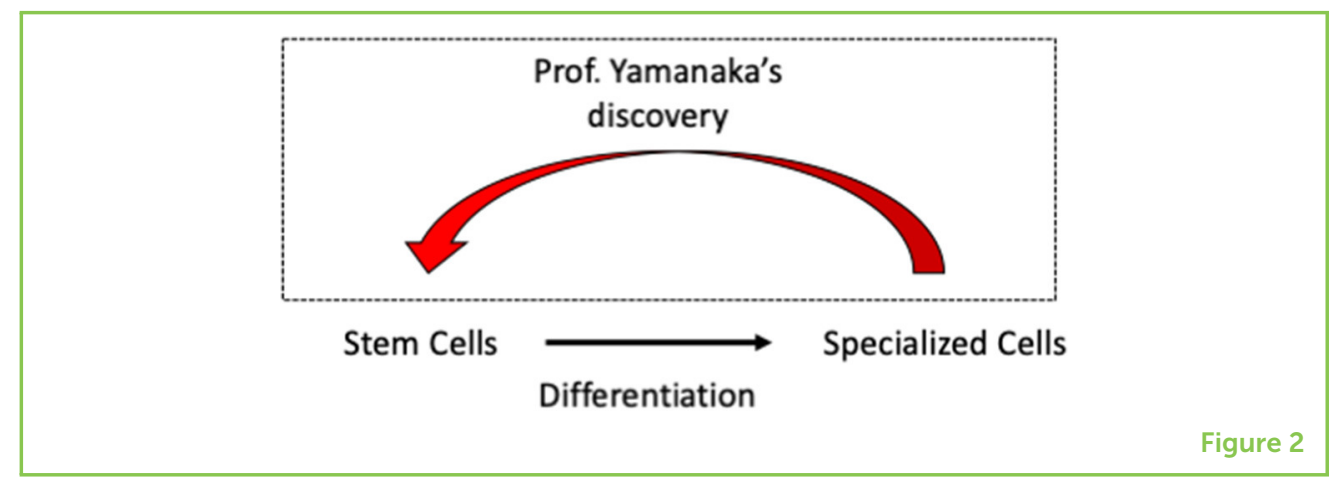


Figure 3

iPSCs can be made into astrocytes in a laboratory dish, in a process that takes more than 60 days. First, astrocytes must be told to become neural progenitor cells. Then, additional chemicals are added that stimulate the neural progenitor cells to become astrocytes.

\section{DIFFERENTIATION}

(di-fuh-ren-shee-ei-shn): The process by which cells become specialized

\section{INDUCED}

PLURIPOTENT STEM CELLS (iPSCS)

Stem cells that have been transformed from specialized cells back into stem cells.

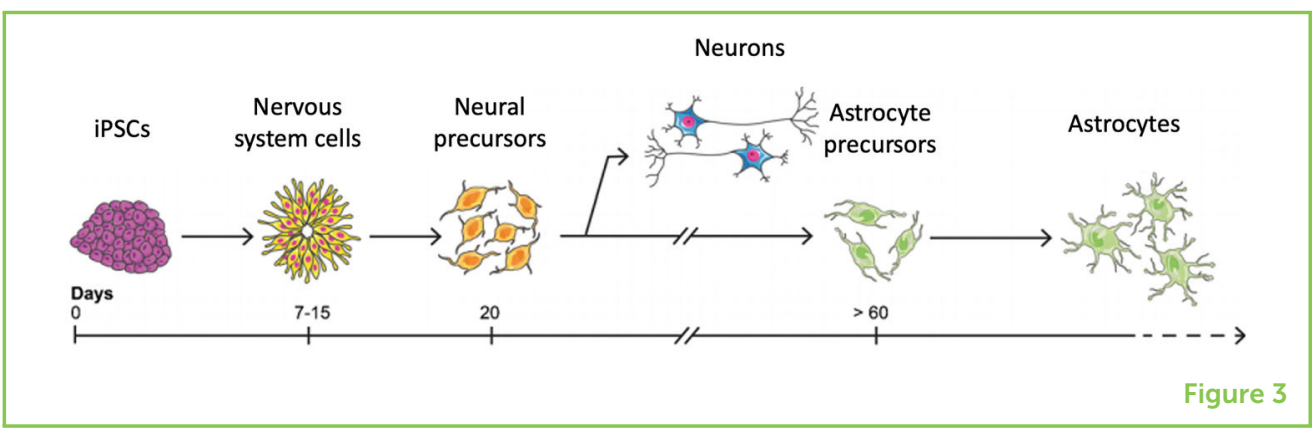

up of more than 30 trillion $(30,000,000,000,000)$ cells! Over time, most of these cells become specialized depending on the job they need to do in the body (neurons, astrocytes, heart cells, liver cells, etc.). This process of becoming specialized is called differentiation. A few cells remain able to keep dividing to make new cells that can differentiate into specialized cells. These cells are called stem cells, as they can make more of themselves-they can self-renew and they have the ability to differentiate into other cell types $[2,3]$.

In 2006, a Japanese scientist named Shinya Yamanaka discovered a way of turning cells that had become specialized back into stem cells. These type of stem cells are called induced pluripotent stem cells (iPSCs) (Figure 2). They are named this way because they have been transformed (induced) to become stem cells and they are able to turn into any specialized cell in the body (pluripotent). For a long time before Yamanaka's work, people did not believe this achievement was possible-turning specialized cells back into stem cells is sort of like turning back time! For this incredible discovery, Prof. Yamanaka won the Nobel prize in 2012.

In a way, iPSCs are like students - they have the potential to be anything they want to be when they grow up, they just need the right guidance at the right time during their education. Scientists have identified the right "guidance" that is needed to turn iPSCs into astrocytes-we can add chemicals to the liquid that we keep the cells in at the right time in the differentiation process to convince the iPSCs to become astrocytes. First, iPSCs are told to turn into the type of cells that will make up the nervous system (Figure 3 ). Then, once they have become cells that could become neurons, called neural progenitor, they are made to turn into astrocytes instead, by growing them for a longer time and adding a different set of chemicals [4].

Importantly, iPSCs can be made from people with different diseases, simply by taking just a small skin sample from them. Then, using Prof. Yamanaka's discovery, these skin cells can be put into a dish and made into iPSCs. The iPSCs can then be differentiated into astrocytes the way we have explained. Today, astrocytes from iPSCs are being used by laboratories all around the world to study Alzheimer's disease, Parkinson's disease, and motor neuron disease [5]. 


\section{CONCLUSION}

An astrocyte is a type of brain cell that is really important for keeping neurons healthy by providing nutrients and controlling blood flow, recycling neurotransmitters, and responding to infection or injury. Problems with astrocytes are now known to contribute to neurodegenerative diseases including Alzheimer's disease, Parkinson's disease, and motor neuron disease. Scientists have discovered ways of growing astrocytes using iPSCs made from skin samples taken from patients with these diseases in a laboratory dish, allowing them to better understand how astrocytes become faulty. By discovering what happens inside astrocytes during disease, scientists can then use this knowledge to design drugs that try to prevent or stop a disease in its tracks.

\section{ACKNOWLEDGMENTS}

Figures 1, 3 were designed using templates from Servier medical art (https://smart.servier.com/).

\section{REFERENCES}

1. Berman, T., and Bayati, A. 2018. What are neurodegenerative diseases and how do they affect the brain? Front. Young Minds 6:70. doi: 10.3389/frym.2018.00070

2. Luk, F., Eggenhofer, E., Dahlke, M., and Hoogduijn, M. 2017. The use of stem cells for treatment of diseases. Front. Young Minds. 5:9. doi: 10.3389/frym.2017.00009

3. Ahuja, C. S., Khazaei, M., Chan, P., O'Higgins, M., and Fehlings, M. G. 2018. Making neurons from human stem cells. Front. Young Minds 6:27. doi: 10.3389/ frym.2018.00027

4. Tyzack, G., Lakatos, A., and Patani, R. 2016. Human stem cell-derived astrocytes: specification and relevance for neurological disorders. Curr. Stem Cell Rep. 2:236-47. doi: 10.1007/s40778-016-0049-1

5. Hall, C., Yao, Z., Choi, M., Tyzack, G. E., Serio, A., Luisier, R., et al. 2017. Progressive motor neuron pathology and the role of astrocytes in a human stem cell model of VCP-related ALS. Cell Rep. 19:1739-49. doi: 10.1016/j.celrep. 2017.05.024

SUBMITTED: 18 March 2020; ACCEPTED: 04 September 2020; PUBLISHED ONLINE: 23 October 2020.

EDITED BY: Nico Sollmann, Technical University of Munich, Germany

CITATION: Clarke B, Devine H, Neeves J and Patani R (2020) Understanding Human Astrocytes: The Neglected Stars of the Brain. Front. Young Minds 8:543855. doi: $10.3389 /$ frym.2020.543855 

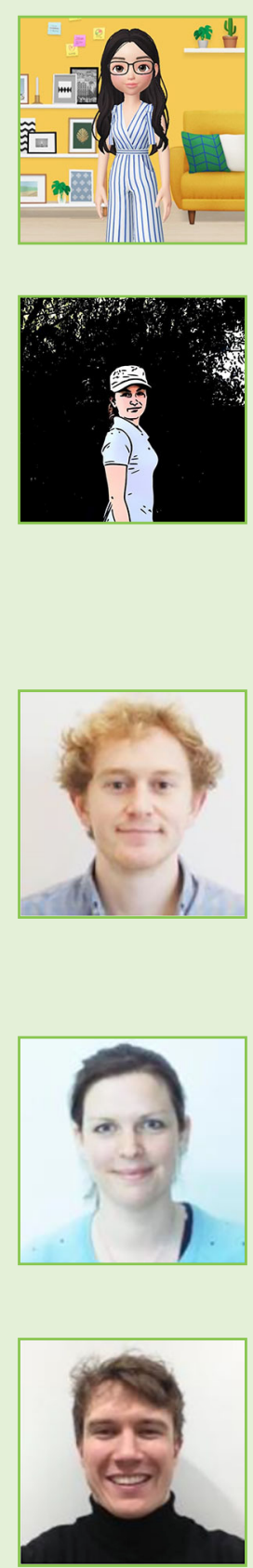

CONFLICT OF INTEREST: The authors declare that the research was conducted in the absence of any commercial or financial relationships that could be construed as a potential conflict of interest.

COPYRIGHT @ 2020 Clarke, Devine, Neeves and Patani. This is an open-access article distributed under the terms of the Creative Commons Attribution License (CC BY). The use, distribution or reproduction in other forums is permitted, provided the original author(s) and the copyright owner(s) are credited and that the original publication in this journal is cited, in accordance with accepted academic practice. No use, distribution or reproduction is permitted which does not comply with these terms.

\section{YOUNG REVIEWERS}

\section{LIJIA, AGE: 13}

LiJia is an avid reader since she was little, she would read most of the books independently she could find in the library or home including thick novels. She is curious about life and how human beings function. She is currently attending Year 8 classes in an international school in Southeast Asia.

\section{MARILIA, AGE: 13}

Hallo! My name is Marilia. I am 13 years old and I like ice skating, rythmic gymnastics, and playing football. I have a small dog which I love! One day I would like to travel to Australia and see the coalas. I enjoy to be with my friends and go swimming or watch a film with them.

\section{AUTHORS}

\section{BENJAMIN CLARKE}

Ben is a post-doctoral researcher in the Patani laboratory interested in astrocytes and their role in neurodegenerative diseases. He obtained his Ph.D. in 2019 at the Institute of Neurology at University College London. *benjamin.clarke.15@ucl.ac.uk; ben.clarke@crick.ac.uk

\section{HELEN DEVINE}

Helen is a neurology doctor, currently undertaking a Ph.D. in neuroscience at UCL Institute of Neurology and the Francis Crick Institute. She uses induced pluripotent stem cells to research a neurodegenerative disease called Kennedy's disease.

\section{JACOB NEEVES}

Jacob is a qualified veterinarian, currently undertaking a Ph.D. in neuroscience at UCL Institute of Neurology and the Francis Crick Institute. His research uses induced pluripotent stem cells to model and examine human neurodegenerative diseases. 


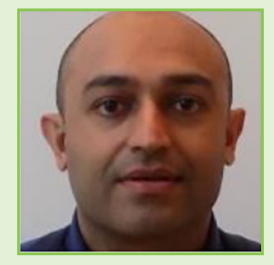

\section{RICKIE PATANI}

Professor Rickie Patani is a physician scientist with over a decade of direct experience working on human induced pluripotent stem cell models of neurodegeneration. 